\title{
Challenges and difficulties encountered by teachers in the conduct of educational research: Basis for teachers' enhancement program
}

Bullo, Marnel M.

Cataingan National High School/SDO Masbate Province, Philippines (Marnel.bullo@deped.gov.ph) Labastida, Ronel T.

Serafin C. Rosero Memorial High School/SDO Masbate Province, Philippines (Ronellabastida0395@gmail.com)

Manlapas, Cherry C.

Panique National High School/SDO Masbate Province, Philippines (Cherry.manlapas@deped.gov.ph)

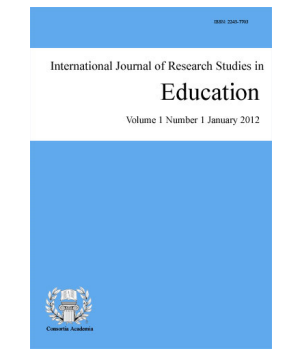

ISSN: 2243-7703 Online ISSN: 2243-7711

OPEN ACCESS

\section{Abstract}

Conducting educational research has become one of the most challenging tasks to most of the teachers, especially because it has been an additional work to them. This study investigated the following questions: a. what is the demographic profile of teacher- researchers in Masbate Province Division? b. What are the challenges and difficulties experienced by teacherresearchers in the conduct of educational research? $\mathrm{c}$. what are the learning and development undertakings received in relation to the conduct of educational research? and d. what solutions could be proposed to resolve challenges and difficulties encountered by teacher- researchers in the conduct of educational research? The study is descriptive in nature. Data were collected from the 50 teacher-researchers' and were analyzed qualitatively. Results of the study revealed that most of respondents encountered challenges in conducting research like the lack of time, have anxieties in writing and conducting the study and perceived research as an additional burden on their part. Additionally, analyzing the quantitative and qualitative data in identifying the issues to be investigated has been a tough challenge to them as well. The good thing about it is that majority of the respondents have undertaken Division Trainings, Graduate studies, and LAC sessions as part of learning and development that helped them to come up with their researches. And so, the researchers of this study, have made an action plan to resolve the challenges and difficulties experienced by the teachers who conducted action research and will be used by the future teacher- researchers.

Keywords: challenges and difficulties, descriptive, educational research, teacher-researchers, Philippines 


\section{Challenges and difficulties encountered by teachers in the conduct of educational research: Basis for teachers' enhancement program}

\section{Introduction}

Making improvements and creating innovations through research truly help every individual equip his or her knowledge with necessary skills. This is also true for most teachers who would like to identify and address every problem in the field. However, creating new knowledge and using that existing knowledge creatively has been very challenging to most teachers in the field of education. In most cases, conducting research is primarily conducted only for compliance, promotion, and requirement.

Many teachers are encouraged to engage in research in today's setting to identify the problems and create a solution. Classroom research, school-based research, teacher research, and action research have been defined in the current study was undertaken and conducted by teachers in the classroom and in the school. This kind of research is done primarily to examine and identify a problem or an issue within the classroom and in the school for which teacher-researchers want to find a solution, by understanding it thoroughly (Burns \& Kurtoglu-Hooton, 2014).

Although it is tough, conducting research can really help teachers develop their knowledge and skills as teachers. Teachers perceive research as an important tool in creating and delivering instructions to students promoting positive learning outcomes. It is also valuable and practical as it would really help the teachers and the students as well. Ulla, Barrera, and Acompanado (2017) also added that; First, teacher-respondents perceived that doing research is essential to their professional growth. They agreed that doing research encourages critical self-reflection, enables them to examine and explore classroom and school problems and their solutions, and develops and enhances their knowledge and skills for classroom teaching. Such findings were congruent to the results of the studies conducted by Hine (2013); Young, Rapp, and Murphy (2010); Hien (2009); and O'Connor, Greene, and Anderson (2006). Hine (2013) stated that teachers who do action research would improve their teaching practice, and its result would be favorable to their students. This was supported by Young et al (2010) when they said that action research can enhance the classroom teaching practice where teachers can observe not just the students' learning process but the learning outcomes as well.

In the contrary, teachers who love to conduct research find it hard to continue because of many factors. According to the research conducted by Ulla, 2018, here are some challenges in conducting research: first, lack of support from the school, referring to financial, work, and training support. Second, lack of sufficient reference materials refers to unavailability of school library and other references which current journals and magazines are needed, even the internet connection. Third, additional workload and burden in the part of the teacher, due to some excessive tasks that the teachers are carrying, conducting research has become a burden and is treated less. Writing anxiety and lack of time are also some of the reasons. Fourth, inadequate knowledge regarding the conduct of action research, because others were not able to get a chance to attend to any trainings regarding research.

Sarkar (2014) also stated the following as the challenges encountered by the teachers in conducting research; first is getting permission for collecting data, second is recruiting intended participants, and problems in using survey questionnaires. However, teachers encountered many difficulties in the conduct of research, but this will lead us to a better way to discover new ideas and strategies in the teaching and learning process.

In this connection, the researchers probed to study the challenges and difficulties teachers encountered in conducting educational research in Masbate province and the country in general, especially their limited studies conducted regarding this matter in the country. The result of the study was the basis in providing enhancement 
program through an action plan as part of the recommendations.

\subsection{Research questions}

The researchers specifically attempted to answer the following questions:

$>$ What is the demographic profile of teacher-researchers in Masbate Province Division?

$>\quad$ What are the challenges and difficulties experienced by teacher-researchers in the conduct of educational research?

$>\quad$ What are the learning and development undertakings received in relation to the conduct of educational research?

$>$ What solutions could be proposed to resolve challenges and difficulties encountered by teacher-researchers in the conduct of educational research?

\subsection{Scope and Limitation}

The study covered teachers who were experienced researchers in the Masbate Province Division. This is limited to the challenges and difficulties experienced by teacher-researchers in Masbate Province, the profile of teacher-researchers, the learning and development undertaking received, and the possible solutions to resolve challenges and difficulties encountered in conducting educational research. This includes the 50 teacher-researchers of the Masbate Province Division as respondents of this study.

\section{Methodology}

This research made use of the descriptive method, which utilized a structured questionnaire that identifies: (a) the demographic profile of teacher-researchers of Masbate Province Division; (b) the challenges and difficulties experienced by teacher-researchers of Masbate Province in the conduct of educational research;(c) the learning and development undertakings received about the conduct of educational research; and (d) the possible solutions that could be proposed to resolve challenges and difficulties encountered by teacher-researchers. The respondents of the study were 50 teacher-researchers who have experienced in conducting educational research. Data was established through analysis of results from the survey questionnaire sent via a google form.

To determine the interpretation answers to research questions cited in the study, the statistical tool used were:

Frequency Count. This was used to determine the occurrences of values within an interval from the respondents' responses or scores. It was used to determine the number of respondents' answers on a 5-point Likert scale.

Percentage. This was used to compute the retrieval percentage, and the demographic profile of secondary school teachers conducted educational research.

Weighted mean. This was used to determine the respondents' mean score in response to the difficulties and challenges encountered in doing their research. 


\section{Results and discussion}

\section{Table 1}

Result in the demographic profile of the teacher-researchers in terms of age

\begin{tabular}{ccccc}
\hline Age & Frequency & Percentage & Rank \\
\hline$<30$ & 19 & $38 \%$ & 2 \\
$>30-40$ & 21 & $42 \%$ & 1 \\
$>40-50$ & 7 & $14 \%$ & 3 \\
$>50-60$ & 3 & $6 \%$ & 0 \\
$>60$ & TOTAL & 0 & $100 \%$ \\
\hline
\end{tabular}

From the given data, here is the result in the demographic profile of the respondents in terms of age. There were 19 respondents who were 30 years old and below, which covers the $38 \%$ of the total population. This shows that teachers who were younger in years really have the drive to push through their careers and have an eagerness to create new ideas. Then, there were 21 respondents who were at the age of 30 to 40 , which covers the $42 \%$ of the total population. These are teachers who can still be considered young and well driven. This only shows that they still have the willingness to uncover the things that they and their learners need in order to acquire more. In addition, there were 7 respondents who were 40- 50 years of age who also conducted research and encountered challenges during the conduct of the research. This covers the $14 \%$ of the total population. This signifies that only few teachers who were in their midlife have the drive to work on their research engagement. However, in this study, there were only 3 respondents with 50-60 years of age who conducted educational research in the province of Masbate, which covers the $6 \%$ of the total population. This implies that only few teachers who are now in their senior years would like to conduct research and make innovations out of the given results.

Table 2

Result in the demographic profile of the teacher-researchers in terms of gender

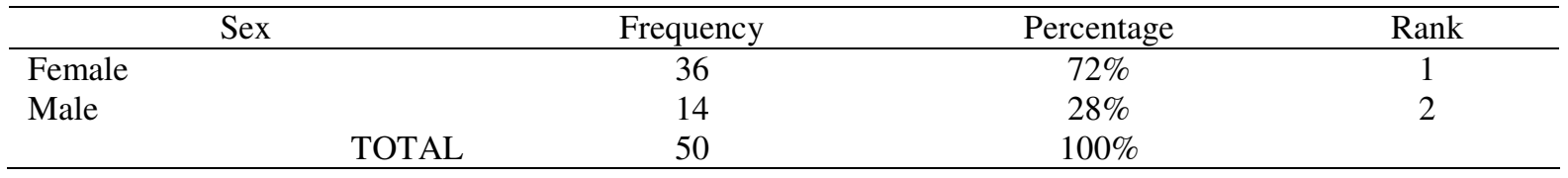

Here is the result in the demographic profile of the teachers in terms of sex. On the data presented, there were 14 males who responded to the survey conducted, this covers the $28 \%$ of the total population. Additionally, there were 36 female teachers who responded to the survey conducted, which covers the $72 \%$ of the total population. On the results given, it shows that most of the time, female teachers can be considered as the ones who have a strong will to conduct research and find more time and effort to exert in doing so in the field of education.

Table 3

Result in the demographic profile of the teacher-researchers in terms of educational attainment

\begin{tabular}{lccc}
\hline \multicolumn{1}{c}{ Educational Attainment } & Frequency & Percentage & Rank \\
\hline Bachelor's Degree Holder & 6 & $12 \%$ & 4 \\
With Masteral Units & 22 & $44 \%$ & 1 \\
Masteral Degree Holder & 10 & $20 \%$ & 3 \\
With Doctorate Units & 11 & $22 \%$ & 2 \\
Doctorate Degree Holder & 1 & $2 \%$ & 5 \\
\multicolumn{1}{c}{ TOTAL } & 50 & $100 \%$ & \\
\hline
\end{tabular}

On the presented data in the demographic profile, here is the result of the teacher-researchers in terms of educational attainment. 6 out of 50 respondents were bachelor's degree Holders, which covers the $12 \%$ of the 
total population. This signifies, that they are really working on their progress as a teacher and as an individual to attain a certain goal for themselves and for the learners. Additionally, there were 22 respondents who were able to conduct basic and action research, which covers the highest percentage in the total population, 44\%. This implies that although doing research is tough, teachers would really work resiliently to come up with a result that would help them as a teacher and their clientele as a whole. Then, there were 10 out of 50 respondents who were master's degree Holders, which cover the $20 \%$ of the total population. In this regard, we can say that teachers were required to accomplish a research as a requirement for graduation, it can also be seen that they try to persevere and finish the degree for fulfillment and promotion.

Additionally, there were 11 respondents, which covers the $22 \%$ of the total population who were with Doctorate Degree units, this also have the same implications on the teachers who were master's degree holders. However, we can also suggest that these teachers really have the strong drive as they would still push themselves to unlock and learn more. Lastly, only 1 teacher, which covers the $2 \%$ of the total population, who was a Doctorate Degree Holder. And this only shows that out of 50 respondents, only one was able to conduct more than one educational research which helped him/her a lot to acquire more.

\section{Table 4}

Result in the demographic profile of the teacher-researchers in terms of teaching position

\begin{tabular}{|c|c|c|c|}
\hline Position & Frequency & Percentage & Rank \\
\hline Teacher I & 13 & $26 \%$ & 2 \\
\hline Teacher II & 11 & $22 \%$ & 3 \\
\hline Teacher III & 20 & $40 \%$ & 1 \\
\hline Master Teacher I & 4 & $8 \%$ & 4 \\
\hline Master Teacher II & 1 & $2 \%$ & 5.5 \\
\hline Head Teacher & 1 & $2 \%$ & 5.5 \\
\hline TOTAL & 50 & $100 \%$ & \\
\hline
\end{tabular}

Table 4 presents the data on demographic profile of teacher-researchers along teaching position. It depicts that $40 \%$ respondents were Teacher III, $26 \%$ were Teacher I, 22\% were Teacher II, $8 \%$ percent were Master Teacher I, $2 \%$ were Master Teacher II and $2 \%$ were Head Teacher I. The data revealed that only $2 \%$ of the respondents as teacher-researchers hold administrative functions, it implies that most of the respondents who have experienced research were classroom teachers. Furthermore, classroom teachers with the lower ranks were more exposed on the endeavor on the conduct of research.

\section{Table 5}

Result in the challenges encountered teacher-researchers

\begin{tabular}{lccc}
\hline \multicolumn{1}{c}{ Challenges } & Frequency & Percentage & Rank \\
\hline $\begin{array}{l}\text { Additional workload and burden in the part } \\
\text { of the teacher }\end{array}$ & 34 & $23 \%$ & 1 \\
$\begin{array}{l}\text { Lack of Time } \\
\text { Writing Anxiety }\end{array}$ & 33 & $22 \%$ & 2 \\
$\begin{array}{l}\text { Lack of Support from the school } \\
\text { Lack of sufficient reference materials }\end{array}$ & 29 & $19 \%$ & 3 \\
$\begin{array}{l}\text { Inadequate knowledge regarding the conduct } \\
\text { of educational research r }\end{array}$ & 19 & $13 \%$ & 4 \\
& 17 & $11 \%$ & 5 \\
& & & 100 \\
\hline
\end{tabular}

Table 5 conveyed that majority of the teacher respondents agreed that the challenges encountered according to rank: additional workload and burden on the part of the teacher (23\%), lack of time (22\%), writing anxiety $(19 \%)$, lack of support from the school (13\%), lack of sufficient reference materials (12\%), and inadequate knowledge regarding the conduct of educational research (11\%). Such results were congruent to the studies conducted by Ellis and Loughland (2016) stated that lack of time and time pressures relative to classroom activities, both extra and co-curricular, and doing research restricted the teachers in Singapore from having 
Bullo, M. M., Labastida, R. T., \& Manlapas, C. C.

quality research. And also, Vásquez (2017) mentioned that heavy teaching loads are why teachers opted not to do research. As teachers compromise with priorities in their workplace, family, and society, they should be given quality time to do what they are expected to do. Furthermore, lack of research training would affect the teachers' interest, confidence, and motivation to do research activities. Sheikh, Kaleem, and Waqas (2013) also noted that participation in research training and courses would positively impact the researchers as they would be exposed to different methodologies, styles, and concepts of doing research. Therefore, research training and seminars should be made available for all these teachers to acquire the necessary knowledge and learn the skills on how to do research. If teachers do not have the skills, they would not be able to carry the task successfully (Ulla, 2016).

Table 6 revealed the difficulties encountered by teacher-researchers. Based on the results shown above, it appears that most of the respondents found it difficult in analyzing qualitative data (1.8), analyzing quantitative data (1.92), identifying issues and problems to be investigated (2.34), developing processes of how to do research and collect evidence (2.38), organizing and writing the findings (2.42) and making a relevant presentation and write an article for publication (2.48). In addition, respondents have also encountered difficulty using technology in statistical analysis (1.88) and data presentation (2.18). These difficulties encountered by respondents are similar to the findings of De Borja (2018) that writing the framework of the study that includes identifying issues or problems, the processes and collecting of evidence and analyzing data appeared to be the most difficult due to the lack of expertise of teachers in identifying variables needed. With this, teachers also have difficulty finding frameworks or theories related to the problems they investigated. Moreover, the table also shown that searching relevant literature and bibliographical entries were found to be neutral.

Table 6

Result in the difficulties encountered by teacher-researchers

\begin{tabular}{lccccccc}
\hline \multicolumn{1}{c}{ Difficulties Experienced } & \multicolumn{3}{c}{ Rating Scale } & \multicolumn{2}{c}{ Overall } \\
\cline { 2 - 8 } & 5 & 4 & 3 & 2 & 1 & WM & DE \\
\hline Identifying issues and problems to be investigated by research & 0 & 1 & 21 & 22 & 6 & 2.34 & Difficult \\
Searching for relevant literature to the chosen research & 1 & 12 & 10 & 26 & 1 & 2.72 & Neutral \\
Developing the processes of how to do research and collect & 0 & 9 & 16 & 23 & 2 & 2.38 & Difficult \\
evidence & & & & & & & \\
Analyzing quantitative data & 0 & 0 & 13 & 20 & 17 & 1.92 & Difficult \\
Analyzing qualitative data & 0 & 9 & 11 & 28 & 2 & 1.8 & Difficult \\
Organizing and writing the findings & 0 & 2 & 25 & 15 & 8 & 2.42 & Difficult \\
Making a relevant presentation and write article for & 0 & 5 & 15 & 29 & 1 & 2.48 & Difficult \\
publication & & & & & & & \\
Using technology in: & & & & & & & \\
A. Literature Search & 0 & 10 & 12 & 23 & 5 & 2.54 & Neutral \\
B. Data presentation & 0 & 4 & 10 & 28 & 7 & 2.18 & Difficult \\
C. Statistical analysis & 0 & 0 & 10 & 24 & 16 & 1.88 & Difficult \\
D. Bibliographical entries & 1 & 22 & 16 & 8 & 3 & 3.1 & Neutral \\
\hline
\end{tabular}

Table 7

Result in learning and development undertakings by teacher-researchers

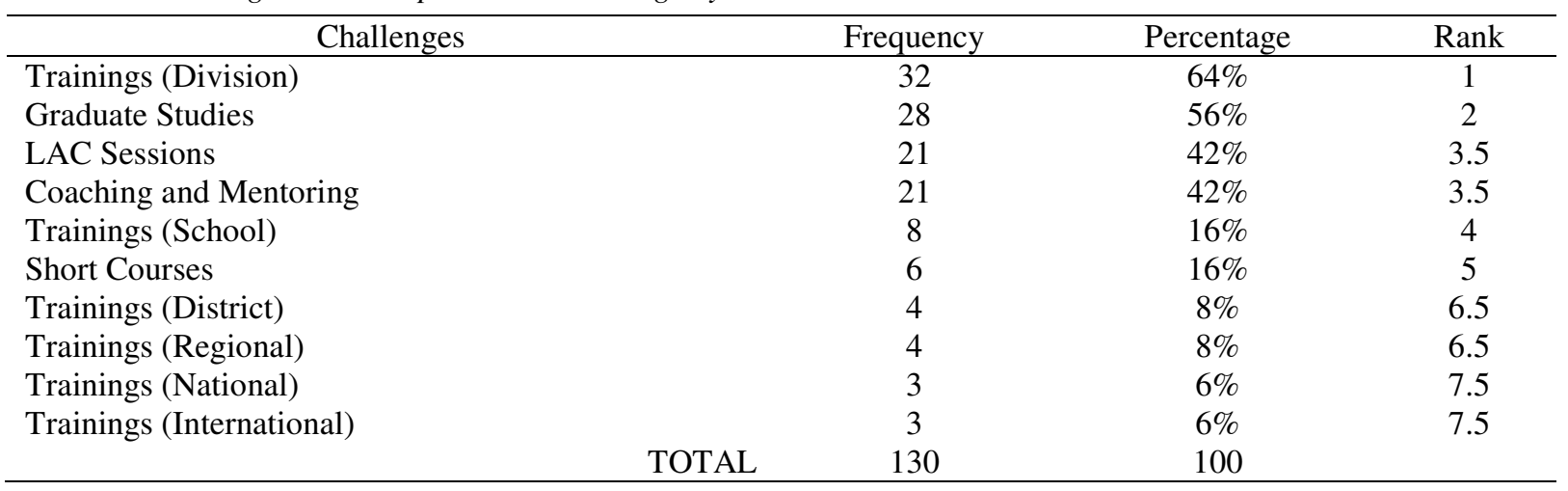

72 Consortia Academia Publishing (A partner of Network of Professional Researchers and Educators) 
Table 7 presents the learning and development undertaken by teacher-researchers. The data shows that among the Learning and Development programs undertaken by the respondents, the division trainings topped with $64 \%$, followed by graduate studies with 56\%, LAC Sessions with 42\%, Coaching and Mentoring with $42 \%$, School-Based Training with $16 \%$, Short Courses with $12 \%$, district and regional training both with $8 \%$, national and international trainings both with $6 \%$. It implies that teacher-researchers are well-quipped to conduct research and have acquired their basic knowledge and skills in research through exposure on these learning and development undertakings.

\section{Conclusions}

Based on the foregoing findings, the following conclusions were drawn:

$>\quad$ Majority of the respondents who experienced conducting research were females, Teacher III, with master's units and their age ranges from 30-40 years old.

$>$ The teacher-researchers were challenged by the lack of time, experienced writing anxiety in conducting research and viewed that it is an additional workload and burden on their part. Furthermore, they also experienced difficulties in analyzing quantitative and qualitative data and identifying issues and problems to be investigated.

$>\quad$ Majority of the respondents have undertaken Division Trainings, Graduate studies, and LAC Sessions as part of learning and development in relation to the conduct of research.

$>\quad$ An action plan can be proposed to resolve the challenges and difficulties experienced by teacher researchers in the conduct of research.

\subsection{Recommendation}

Based on the results of the study, some recommendations were made:

$>$ Teachers should be given sufficient seminars, trainings, and workshops on research, and they must religiously attend to these to acquire research skills and processes so that they can come up with quality research;

$>\quad$ School Heads and Administrators should extend their support to teachers by sending them to research seminars, training, workshops, and other activities designed for them to be more prepared in conducting research and develop a growth mindset of time-management, prioritization, and professional development;

$>$ Teaching workloads and other teaching tasks should be reduced so that teachers will have enough time and be able to produce quality research;

$>\quad$ Future Researchers should conduct further researches related to this study to deepen the study to a different extent, and to address specific research problems of classroom teachers mainly; and

$>\quad$ The action plan on teachers' enhancement program developed in this study should be implemented to help teachers avoid problems in the future conduct of their research. 
Bullo, M. M., Labastida, R. T., \& Manlapas, C. C.

\subsection{Action Plan}

\begin{tabular}{|c|c|c|c|c|c|}
\hline $\begin{array}{l}\text { Goals and } \\
\text { Objectives }\end{array}$ & Strategies / Activities & Time Frame & Persons Involved & $\begin{array}{l}\text { Materials } \\
\text { Needed }\end{array}$ & Expected Output \\
\hline \multirow{3}{*}{$\begin{array}{l}\text { To acquire } \\
\text { teacher's } \\
\text { research skills }\end{array}$} & $\begin{array}{l}\text { Assess teachers' skills and } \\
\text { capabilities in conducting a } \\
\text { research. }\end{array}$ & $\begin{array}{l}\text { September-October } \\
\text { (First Quarter) }\end{array}$ & School Heads & Assessment Tool & Validated Results \\
\hline & $\begin{array}{l}\text { Identify the following based on } \\
\text { the assessment results: } \\
\text { 1. Strengths of teachers in } \\
\text { research; and } \\
\text { 2. Weaknesses of teachers in } \\
\text { research }\end{array}$ & $\begin{array}{l}\text { September-October } \\
\text { (First Quarter) }\end{array}$ & School Heads & & Categorized list \\
\hline & $\begin{array}{l}\text { Seek the support from Division } \\
\text { Planning \& Research Office for } \\
\text { the intervention and capacity } \\
\text { training/workshop }\end{array}$ & $\begin{array}{l}\text { November-January } \\
\quad\left(2^{\text {nd }} \text { Quarter }\right)\end{array}$ & $\begin{array}{l}\text { School Heads } \\
\text { SEPS in Research } \\
\text { \& Planning } \\
\text { Teachers }\end{array}$ & $\begin{array}{l}\text { Research Design } \\
\text { Training Matrix }\end{array}$ & $\begin{array}{l}\text { Quality research } \\
\text { output }\end{array}$ \\
\hline \multirow{3}{*}{$\begin{array}{l}\text { To promote } \\
\text { research } \\
\text { culture to } \\
\text { teachers } \\
\text { within the } \\
\text { school level }\end{array}$} & $\begin{array}{l}\text { Conduct In-Service Training } \\
\text { (INSET) with all the teachers. }\end{array}$ & $\begin{array}{l}\text { February-April } \\
\left(3^{\text {rd }} \text { Quarter }\right)\end{array}$ & $\begin{array}{c}\text { School Heads } \\
\text { Department Heads } \\
\text { Resource Speakers } \\
\text { Teachers }\end{array}$ & $\begin{array}{c}\text { Matrix } \\
\text { Training Design }\end{array}$ & $\begin{array}{l}\text { Research Output } \\
\text { Presentation } \\
\text { Accomplishment } \\
\text { Report }\end{array}$ \\
\hline & $\begin{array}{l}\text { Organize a focus group } \\
\text { discussion (FGD) to determine } \\
\text { the following: } \\
\text { 1.Issues/problems experienced } \\
\text { that are to be investigated for } \\
\text { research; } \\
\text { 2. Task reduction and proper } \\
\text { scheduling or assigning of tasks } \\
\text { for teachers for them to have } \\
\text { enough time in conducting } \\
\text { research }\end{array}$ & $\begin{array}{l}\text { February-April } \\
\left(3^{\text {rd }} \text { Quarter }\right)\end{array}$ & $\begin{array}{c}\text { School Heads } \\
\text { Department Heads } \\
\text { Teachers }\end{array}$ & & $\begin{array}{l}\text { Come-up issues to } \\
\text { be investigated }\end{array}$ \\
\hline & $\begin{array}{l}\text { Conduct feed backing sessions } \\
\text { on the conduct of educational } \\
\text { research. }\end{array}$ & $\begin{array}{l}\text { May-July } \\
\text { (4 }\end{array}$ & $\begin{array}{c}\text { School Heads } \\
\text { Department Heads } \\
\text { Teachers } \\
\end{array}$ & & $\begin{array}{l}\text { Accomplishment } \\
\text { Reports }\end{array}$ \\
\hline \multirow{2}{*}{$\begin{array}{l}\text { To develop } \\
\text { teachers' } \\
\text { research skills } \\
\text { and } \\
\text { competencies }\end{array}$} & $\begin{array}{l}\text { Encourage teachers to attend } \\
\text { trainings and short-term } \\
\text { courses to enhance capabilities } \\
\text { research. }\end{array}$ & Year -round & $\begin{array}{c}\text { School Heads } \\
\text { Department Heads } \\
\text { Teachers } \\
\text { LGU's } \\
\text { NGO's } \\
\end{array}$ & & $\begin{array}{l}\text { Accomplishment } \\
\text { Reports }\end{array}$ \\
\hline & $\begin{array}{l}\text { Encourage teachers to pursue } \\
\text { graduate studies }\end{array}$ & Year -round & & & \\
\hline
\end{tabular}

Acknowledgement - The researchers are pleased to put on the list the following individuals who have helped them in completing this study: First, a heartfelt thanks to their instructor, Dr. Cheryll Bermudo, who motivated them to come up with a basic research that helped them enhance their knowledge and skills in crafting research. To the respondents, who have helped them a lot with the data needed and made this study possible. Thank you for your time and cooperation. Above all, to Abba Father who have guided us all throughout and have provided and given us knowledge, wisdom, and talent to finally finish this study, they give thanks, honor, and glory to Him alone. Thank you to all who have been a great help and a blessing to make this research possible. 


\section{References}

Al-Hadabi, A. S. D., \& Asoudi, M. S. A. (2020). Scientific research hypotheses understanding of the pre-service science teachers at faculty of Education-Amran University, Yemen. Educational Research and Reviews, 15(9), 544-553. https://doi.org/10.5897/ERR2020.3994

Atkinson, R., McBeath, C., Coffey, A., Etherington, S., Martin-Lynch, P., Moore, C., ... \& Philips, R. (2013). Special issue: Teaching and learning in higher education. Western Australia's TL Forum.

Bughio, F. A. (2015). Issues and challenges in doing action research in a public sector university. Journal of Research in Social Sciences, 3(1), 86-95

Burns, A., \& Kurtoglu-Hooton, N. (2014). Implementing action research in the modern language classroom. Scottish Languages Review, 27(Spring/Summer), 21-28.

Cain, T., \& Milovic, S. (2010). Action research as a tool of professional development of advisers and teachers in Croatia. European Journal of Teacher Education, 33(1). https://doi.org/10.1080/02619760903457768

Ellis, N., \& Loughland, T. (2016). The challenges of practitioner research: A comparative study of Singapore and NSW. The Australian Journal of Teacher Education, 41(2). https://doi.org/10.14221/ajte.2016v41n2.8

Hine, G. S. (2013). The importance of action research in teacher education programs. Issues in Educational Research, 23(2), 151-163.

Kurtoglu-Hooton, N. (2014). Implementing action research in the modern language classroom. Scottish Languages Review \& Digest, 21.

Lari, P., Rose, A., Ernst, J., Clark, A., Kelly, D., \& DeLuca, V. (2019). Action research. Technology and Engineering Teacher, 79(2), 23.

Norasmah, O., \& Chia, S. Y. (2016). The challenges of action research implementation in Malaysian schools. Pertanika Journal of Social Science and Humanities, 24(1), 43-52.

O'Connor, K. A., Greene, H. C., \& Anderson, P. J. (2006). Action research: A tool for improving teacher quality and classroom practice. Online Submission.

Sarkar, M. (2014). Challenges in conducting educational research: The case of a developing country. Contemporary approaches to Research in Mathematics, Science, Health and Environmental Education.

Ulla, M. B. (2018). Benefits and challenges of doing research: Experiences from Philippine public school teachers. Issues in Educational Research, 28(3).

Young, M. R., Rapp, E. M., \& Murphy, J. (2010). Action research: Enhancing classroom practice and fulfilling educational responsibilities. Sociology, Journal of Instructional Pedagogies, 3. 
Bullo, M. M., Labastida, R. T., \& Manlapas, C. C.

76 Consortia Academia Publishing (A partner of Network of Professional Researchers and Educators) 